\title{
DATE CORRECTION OF OMAR BIN KHATTAB'S DEATH IN AN ASTRONOMICAL PERSPECTIVE
}

\author{
Akhmad $\mathcal{N a d i r i n}{ }^{1}$, M. Ihtirozun $\mathcal{N i}^{\prime}{ }^{\prime} m^{2}$ \\ ${ }^{1}$ Universitas Islam Negeri Walisongo Semarang, ${ }^{2}$ Universitas Islam Negeri Walisongo \\ Semarang \\ 1'nadirin0711@gmail.com, ${ }^{2}$ ihtirozun_n@walisongo.ac.id
}

\section{Abstract}

Omar bin Khattab was a companions of Prophet Muhammad SAW who had the title as Amir al-Mu'minin. He led Islam for about 10 years before being stabbed by Abu Lu'luah when he was in the morning prayer at the end of the $23 \mathrm{rd} H$ year until death. There are many opinions in Islamic historical literature about the death of Omar bin Khattab. Some experts say that 3, 4 or 7 days left in Dzulhijjah 23 H or the Sunday of Muharram 24 H. This study is intended for the first, knowing why there is a difference in the death data. Second, answering the problems of correction Omar bin Khattab's death data in an astronomical perspective. These problems are discussed with a qualitative research in the form of library research. The primary sources used in this study are Tārikh al-Thabari Tārikh al-Umam wa al-Mulūk, Ashāb al-Futuyāa, al-Kāmil fĩ al-Tārikh, Siyar A'lam al-Nubulā, al-Bidāyah wa al-Nihāyah. Furthermore, the data obtained is converted into days and dates then it is cohered with the appropriate data. The result of this study shows that there is the difference of Omar bin Khattab's death data. It is caused by the difference theories of the data. Thus, based on the astronomical calculation, the date of Omar bin Khatab's death was on Wednesday, $26^{\text {th }}$ Dzulhijjah $23 \mathrm{H} / 3^{\text {rd }}$ of November $644 \mathrm{M}$ (3 days left in the month Dzulhijjah $23 \mathrm{H}$ ).

Keywords: date correction, death, Omar bin Khattab, astronomy

\section{Abstrak}

Omar bin Khattab merupakan sahabat Nabi SAW yang bergelar Amirul Mukminin. Ia memimpin Islam selama lebih kurang 10 tahun sebelum ditikam oleh Abu Lu'luah ketika beliau sedang shalat subuh pada akhir tahun $23 \mathrm{H}$. Terdapat banyak pendapat dalam literatur-literatur sejarah Islam tentang data tanggal wafatnya Omar bin Khattab. Ada yang mengatakan 3, 4 atau 7 hari sebelum akhir bulan Dzulhijjah $23 \mathrm{H}$ atau Ahad bulan Muharram tahun $24 \mathrm{H}$. Studi ini dimaksudkan untuk pertama, mengetahui mengapa terjadi perbedaan data tanggal 
wafat, kedua menjawab permasalahan koreksi data tanggal wafat Omar bin Khattab dalam perspektif astronomi. Permasalahan tersebut dibahas dengan penelitian kualitatif yang berupa penelitian kepustakaaan (library research). Sumber primer yang digunakan dalam penelitian ini adalah Tārikh al-Thabari Tārikh al-Umam wa al-Mulūk, Ashāb al-Futuyāa , al-Kāmil fĩ alTārikh, Siyar A'lam al-Nubulā, al-Bidāyah wa al-Nihāyah. Semua data yang diperoleh kemudian dikonversi baik ke dalam hari maupun tanggal masehi dan dicocokkan kesesuaian data-data tersebut. Hasil penelitian menunjukan perbedaan tanggal wafat Omar bin Khattab disebabkan karena banyaknya jalur periwayatan yang berbeda-beda. Adapun tanggal wafat berdasarkan perhitungan astronomi adalah Rabu, 26 Dzulhijjah 23 H/3 November 644 M (3 hari sebelum akhir bulan Dzulhijjah $23 \mathrm{H}$ ).

Kata kunci : koreksi, wafat, Omar bin Khattab, astronomi

\section{A. Introduction}

Omar bin Khattab is one of Prophet Muhammad's companions who included in Khulafāur Rāshidīn and become the second kholīfah after Abu Bakr al-Shiddiq with the title as Amīr al-mu'minīn. Khulafāur Rāshidīn is a term used to refer to the period and a straight leadership system after Prophet Muhammad. ${ }^{1}$ Omar bin Khattab also belonged to al-Sābiqūna al-Awwalūn (people who first converted to Islam) and al-Asyroh alMubāsysyirūna bi al-Jannah (Ten companions who were guaranteed to go to heaven). ${ }^{2}$

Talking about history, it's can not to be separated from the place and time of the incident. Likewise with the history of Omar bin Khattab, especially with regard to data on the date of his death. After Abu Bakar died, kholiffah was continued by Omar bin Khattab for 10 years 6 months 4 days. ${ }^{3}$ Omar was killed in the remaining 3 days and even 7 days left of Dhu al-Hijjah. ${ }^{4}$ Another opinion says that Omar was killed on Wednesday, the remaining 4 days of Dhu al-Hijjah $23 \mathrm{H}$ and died on Sunday the month of Muharram $24 \mathrm{H}^{5}$

${ }^{1}$ Abdullah Munib El-Basyiry, Meneladani Kepemimpinan Khalifah : Khulafaur Rasyidin dan Khalifah Pilihan, Jakarta : Amzah, 2017

${ }^{2}$ Muhammad Ahsa Isa dalam karyanya Sepuluh Sahabat Nabi dijamin Masuk Surga menyebutkan Surga yaitu Abu Bakar, Omar, Utsman, Ali, Thalhah, Zubeir, Abdurrahman bin 'Auf, Sa'ad, Sa'id dan Abu Ubaidah bin Jarah

${ }^{3}$ Samsul Munir Amir, Sejarah Peradaban Islam, Jakarta: Amzah, 2009, Hal 103

${ }^{4}$ Ibnu Katsir, Bidayah wa Nihayah, Juz 7, Beirut: Dar al-Kutub al-Ilmiyah, Hal 111-112

${ }^{5}$ Ibnu Atsir, al-Kamil fi at-Tarikh Jilid 2. Beirut: Dar al-Kitab al-Ilmiyyah. 1998 M/1418 Hal 448. Imam al-Dzahabi in Siyar A'lam an-Nubala on page 329 said that omar bin khattab death at four days remains in Dzulhijjah $23 \mathrm{H}$ 
Based on searching of various sources, there were many differences of opinion regarding the data on the date of Omar bin Khattab's death. The difference of Omar bin Khattab's death data in various Islamic history book is interesting to be explored further because death is an event that only happened once. There are differences that involve differences in dates, months and years. These opinions are just accepted without checking it's validity firstly. Therefore scientific research is needed to find out the truth and validity of the death's data.

There aren't many Muslims correct the validity of historical data from astronomical calculations prespective. This also happened on Omar bin Khattab's death date data. It's because of one fact that examining the validity of information is not an easy thing to do certainly, in view of writing a data information in any opuses has a fairly long period of time until now. Therefore, scientific expertise is needed to determine the validity of data on death's date also the percision correction based on the astronomical approach.

The difference of writting a time and chronological dates in the Islamic history books, especially those concerning in important issues such as the death of Omar bin Khattab, was caused by several factors. Among of these factors is the differences of opinion in determining the begining of Islamic month, adjustment in calculations between the Gregorian Calendar and Islamic calendar, differences in the conversion system methode. It's a difficult problem. On the one hand, writing history is required to find factually a track record of the kholifah. On the other hand, it also should not ignore the opinions of companions, tabiin and islamic schoolars in any references.

The difference of Omar's death data in Islamic history literature is interesting to be studied. A previous study about Islamic history and astronomy is Muthiah Hijriyati's research entitled "Reconstruction of the Sirah Nabawiyyah (Gazwah Analysis in Astronomy Prespective)". In this study, the results obtained that thare are accordances between the war data in the Sirah Nabawiyyah with result of astronomical calculations. It can make strengthen the existing data. But also, there are contradictory opposite results. This research will discuse a spesific case to find the cause of the differences in the data of Omar bin Khattab's death in Islamic history literature. In addition, it was also to find the 
correction data of Omar bin Khattab's death date from an astronomical perspective. This is very interesting because Omar is known as the originator of the Hijriyah calendar. And he died after the enactment of Hijriyah calendar. So this research is quite interesting to examine the applicability and accuracy of the data in the submission of Hijriyah calendar.

\section{B. RESEARCH METHODS}

This type of research is a qualitative research in the form of library research. The primary sources used in this study are the books of Islamic history including al-Bidāyah wa al-Nihāyah by Ibn Katsir, Tārikh al-Thabari Tārikh al-Umam wa al-Mulūk the work of Abu Ja'far Muhammad ibn Jarir Ath-Tabari, Ashāb al-Futuyā by Imam Abi Muhammad Ali bin Ahmad bin Said bin Khazm al-Andalusi, al-Kāmil fí al-Tārikh by Ibnu Atsir, Siyar A'lām al-Nubalā' by Imam Syamsuddin al-Dzahabi. The selection of these books is because we will present the differences data of Omar bin Khattab's death. Well, it is for the astronomy literarures that will be used in this research are the Celestial Mechanics by Rinto Anugraha, Astronomical Algorithms by Jean Meeus and so on. In addition, secondary sources in the form of books or articles on the history of the Prophet's companions and astronomy were also used to sharpen the analysis of research.

This research focuses on historical and astronomical studies, the research steps are as follows: first, identification of the date of Omar bin Khattab's death in various books of Islamic history. After that, the data will be grouped, whether mutually reinforcing or even contradictory. In addition, it was also identified to look for data on the more famous opinion about his date of death. second: calendar conversion, convert data of the death's date, ${ }^{6}$ because as is known that almost all of the data is arranged in the form of the Hijriyyah calendar, while the Gregorian Calendar is absolutely necessary because astronomical calculations are referenced in the Gregorian Calendar. Third, data analysis. In managing the data found, the authors use the method of astronomical death

\footnotetext{
${ }^{6}$ This conversion is done by changing the hijriyyah calender to Julian Day, then changing it to the gregorian calender. In this case, what is used is the theory of Jean Meeus which cinsidered representative.
} 
data conversion. So that, it will be obtained a correction of the data of Omar bin Khattab's death date that is valid astronomically .

\section{DISCUSS AND RESULT}

\section{C.1. Islamic History and Its Relation to Astronomy}

The history of Khulafaur Rāsyidin is a string of important events in Islamic history. Khulafaur Rāsyidīn is a term used to refer to the period and a leadership system after Prophet Muhammad. There are Abu Bakar al-Shiddiq, Omar bin Khattab, Uthman bin Affan and Ali bin Abi Talib. ${ }^{7}$

History can not be separated from the place and time, more than for a big figure. Likewise with the history and death of Omar bin Khattab. It is important, especially to find out when we have to remember it in the context of setting an example from that figure. But, there are differences in the data of the death of Omar bin Khattab in various Islamic historical literature. Though death is an event that only happens once. Therefore we need a scientific search with astronomical calculations to find out the correction of the death data which is more valid.

Correction according to the big Indonesian dictionary has the meaning of 1) correction; examination; 2). Correction of errors (in trial, script, etc.); rectification of the results of the arrangement to suit the example; 3 ). reading and correcting the trial print with certain signs to ensure the compatibility of the trial print with the manuscript; 4). examination results. ${ }^{8}$ Whereas, death means the death (usually for the king, famous big people).

Astronomy itself has a simmilar means with reckoning, falak, mīqūt, rasdu, and haiah. ${ }^{9}$ In the Big Indonesian Dictionary, astronomy is interpreted as a science of

\footnotetext{
${ }^{7}$ Abdullah Munib El-Basyiry, Meneladani Kepemimpinan Khalifah : Khulafaur Rasyidin dan Khalifah
} Pilihan, (Jakarta : Amzah, 2017)

${ }^{8}$ Badan Pengembangan dan Pembinaan Bahasa, Kementerian Pendidikan dan Kebudayaan Republik Indonesia, Kamus Besar Bahasa Indonesia Edisi Kelima, Kamus Digital KBBI V 0.2.1 Beta (21) Dirilis 27 Oktober Tahun 2016. Update terakhir 12 April 2018

${ }^{9}$ Susiknan Azhari. Ilmu Falak Perjumpaan Khazanah Islam dan sains Modern. (Yogyakarta : Suara Muhammadiyah, 2007). Hal 98 
the sun, moon, stars and other planets or also called Falak Science. ${ }^{10}$ Whereas, according to Ahmad Izzuddin, this science discusses about orbit of celestial bodies like Earth, Moon, and Sun. ${ }^{11}$ Celestial bodies are moving according to their respective orbits. With these orbits, it can be used to determine the position of celestial bodies between one another. It is the basic for calculating the calendar.

\section{C.2. Gregorian calendar}

The modern calendar based on moving of the Sun is called the Gregorian Calender modified by Pope Gregory XIII in 1582. This calendar is based on the circulation of the Earth around the Sun where for one cycle requires 365.2425 days. Among of advantages of this calendar is a suitability of the season because this calendar makes changes in the seasons, from winter, spring, autumn to winter again and so on an annual basis as one of the initial elements of its determination.

This change in season is due to the position of the Earth's axis of rotation which is not perpendicular to the plane of Earth's orbit around the sun. The earth's equatorial plane forms an angle of about $23.5^{\circ}$ to the earth's orbital plane around the sun (the ecliptic plane). For observers on Earth's planet with a northern latitude of less than $66.5^{\circ}$ and southern latitudes of more than $-66.5^{\circ}$ will see the sun's movement throughout the year among 13 ecliptic constellations (Pisces, Aries, Taurus, Gemini, Cancer, Leo, Virgo, Libra, Scorpius, Ophiucus, Sagittarius, Capricorn, and Aquarius).

As an effect of the celestial equator and the ecliptic is not a plane, in a year observers on earth will see the sun crossing the celestial equator twice. First, when the Sun moves from the southern hemisphere to the northern hemisphere (sometimes on $21^{\text {st }}$, sometimes March $22^{\text {nd }}$ ) that named as the vernal equinox (spring point or Aries point). Second, when the sun crosses from the northern sky to the southern sky (sometimes on September $22^{\text {nd }}$ and $23^{\text {rd }}$ ) than named as autumnal

\footnotetext{
${ }^{10}$ Badan Pengembangan dan Pembinaan Bahasa, Kementerian Pendidikan dan Kebudayaan republik Indonesia, Kamus Besar Bahasa Indonesia Edisi Kelima, Kamus Digital KBBI V 0.2.1 Beta (21) Dirilis 27 Oktober Tahun 2016. Update terakhir 12 April 2018

${ }^{11}$ Ahmad Izzuddin, Ilmu Falak Praktis, Semarang: Pustaka Rizki Putra, 2012. Hal 1
} 
equinox (autumn point). The middle between vernal equinox with autumnal equinox is summer and winter solstices where the sun is at this point on June $21^{\text {st }}$ and December $21^{\text {st }}$ or $22^{\text {nd }}$. When the Sun is in the direction of spring point (March $21^{\text {st }}$ ) and autumn point (September $23^{\text {rd }}$ ), the Sun rises in the east and sets in the west.

The earth's revolution around the Sun and the tilt of the Earth's axis towards ecliptic (around $66.5^{\circ}$ ) causes an annual four-season arrangement in the northern and southern hemisphere or the dry season and rainy season in areas close to the equator. Therefore, the Gregorian calendar system can be used as a sign to recognize the general pattern of annual season changes. This Gregorian calendar is currently being applied internationally now.

In other words, this calculation is based on the apparent circulation of the Sun which is started when the sun at the Aries point until it returns to that point. The begining calculation from this point is not without reason. This happens because the annual orbit of the Sun is not coincide with the celestial ecliptic. This path is tilted and forms an angle $23^{\circ} 27^{\prime}$.

From this, it can be understood if the point of intersection between the equatorial and ecliptic circles occurs twice, when the Sun moves from the southern sky to the north (Aries or vernal equinox point) and from the northern sky to the south (Libra point or autumnal equinox).

\section{C.3. Hijriyah Calendar}

The hijriyyah calendar is also known as the lunar calendar because its calculations are based on the Moon motion around the Earth. This hijriyyah year firsly was introduced during the khalifah Omar bin Khtattab after 2.5 years after he was appointed as Amir al-Mu'minin. It is coincided with the seventeenth year after the Prophet's migration. ${ }^{12}$

\footnotetext{
${ }^{12}$ Arwin Juli Rakhmadi Butar-Butar, Problematika Penentuan Awal Bulan : Diskursus antara Hisab dan Rukyat, Malang: Madani ( Kelompok Intrans Publishing), 2014 Hal. 95
} 
The lunar calendar is a calendar calculation system based on the movements of the Moon when it evolved against the earth. This calendar is purely based on the changes of the Moon phases. So, the change of season does not effect its existence. Calculations in the lunar calendar are different from the solar calendar. The calculation of one month in the lunar calendar is from ijtima' (conjunction) to the next ijtima'. This month's movement is divided into two types namely the ciderical cycle and the synodic cycle. The ciderical cycle is the period needed by the moon to circle the Earth with a reference based on a distant star or the time that needed for the Moon to circle the earth for one full turn. In this cycle, the moon takes 27.321582 days or 27 days 7 hours 43 minutes 11.6 seconds.

While the synodic cycle is the time needed by the Moon to circle the Earth exactly one rotation with an observer's reference from the sun or the time required by the moon to circle the earth from one conjunction to the next conjunction. The time needed by the month in the synodic cycle is longer than the time of the sidereal cycle, which is 29.530589 days.

From the two Moon cycles, the period used in calendar calculations is a synodic cycle. So that the age in one month is between 29 or 30 days. Therefore, if there are 12 months in a year, then the age of the year is 354 days 58 minutes 34 seconds. Among the calendars that use this system are the Hijriyyah, Saka and Islamic Javanese calendars.

The calendar in the Hiriyyah calendar can be converted into the Gregorian calendar, and vice versa from the Gregorian calendar into the Hijriyyah calendar. One way that can be used in the conversion system is the Julian Day conversion system. Julian Day is a countdown of days that even starts before Julian calendar used.

\section{C.4. Characteristics of Gregorian Calendar and Julian Day}

Before the conversion process, the characteristics of each calendar must be known first. The characteristics of the Gregorian calendar are as follows: ${ }^{13}$ first, the

\footnotetext{
${ }^{13}$ Muhyidin Khazin, Ilmu Falak : Dalam Teori dan Praktik, Yogyakarta: Buana Pustaka, 2008, Hal. 105
} 
average age of the calendar is 365.25 days with 1 year has age 366 days if in leap year and 365 days in other year; second, a leap year is a number that is divisible by 4 , except the century number. It must be divisible by 400 . There is one cycle in four years, meaning 3 years in the form of a basic year with 365 days and one year as fulfillment or a leap year with 366 days; third, one cycle is 4 years with 1,461 days; fourth, there is a correction of Gregory which currently amounts to 13 days

Then, the characteristics of the hijriyyah calendar are: ${ }^{14}$ first, the average age of each year is 354 days 8 hours 48 minutes 36 seconds or $35411 / 30$ days; second, there is one cycle every 30 years with 11 leap years and 19 basic years; third, the age in one cycle is 10,631 days; ${ }^{15}$ Fourth, the beginning of the hijriyah calendar and the gregorian calendar is not same, so the two calendars have a day difference. The difference between that two calendars is 227,016 days ${ }^{16}$

Calendar conversion is moving from one calendar calculation system to another. There are various ways and methods offered in calculating conversions. But, by changing a Julian calendar system to Gregorian, it creates its own difficulties when comparing astronomical events that are spaced long enough. ${ }^{17}$ Therefore, there is a Julian Day ${ }^{18}$ calculation to compare days and dates far enough back. In general, the function of Julian Day is: ${ }^{19}$ first, to calculate the position of celestial bodies such as the Moon and Planets which can be used to determine the new moon, prayer times and so on. second, as a basis for determining natural phenomena, such as

${ }^{14}$ Abd. Salam Nawawi, Ilmu Falak: Cara Praktis Menghitung Waktu Shalat, Arah Kiblat, dan Awal Bula, Sidoarjo: Aqaba, 2010, Hal.52-54. Begitu juga dinyatakn oleh Ahmad Musonnif dalam karyanya Ilmu Falak: Metode HisabAwal Waktu Shalat, Arah Kiblat, Hisab Urfi dan Hisab Hakiki Awal Bulan, Yogyakarta: Teras, 2011, Hal. 105-111

${ }^{15}$ This value got caculate $19 \times 354+11 \times 355=10.631$

${ }^{16}$ Terdapat perbedaan pendapat kapan mengenai 1 Muharram $1 \mathrm{H}$. berdasarkan rukyah, 1 Muharram jatuh pada hari Jum'at, 16 Juli 622 M, sedangkan berdasar Hisab jatuh pada hari Kamis, 15 Juli 622 M. (al Thai, $2007: 257$ )

${ }^{17}$ Rinto Anugraha, Mekanika Benda Langit, Yogyakarta: tp, 2012 Hal. 8

${ }^{18}$ Julian Day berbeda dengan Julian Date atau tanggal dalam kalender Julian. Menurut Jean Meeus, tanggal Julian dimaknai sebagai hari yang ada di kalender Julian dan kalender ini otomatis tidak digunakan lagi stetelah ada reformasi Gregorian. Sementara Julian Day lebih pada perhitungan hari secara mundur yang bahkan dimulai sebelum tanggal Julian diberlakukan.

\footnotetext{
${ }^{19}$ Rinto Anugraha, Mekanika Benda Langit, Yogyakarta: tp, 2012, Hal 8
} 
determining the tilt of the Earth's rotational orbit, calculating the occurrence of equinoxes, solstices and so on.

Julian day itself is understood as the number of days passed since Monday, January $1^{\text {st }}, 4713$ BC $^{20}$ at 12:00:00 UT (Universal Time) or GMT (Greenwich Mean Time) or the count of days and their fractions continuously from the beginning of the year $-4712 .{ }^{21}$ Since the calculation only starts at 12 noon, the count for that day is $1 / 2$ JD. To convert from hijriyyah to gregorian or vice versa is by converting it's calendar into Julian Day firstly. Then, form Julian Day form, it is converted back into Hijriyyah or gregorian calendar.

\section{C.5. Count Days and Five-Day Week (Pasaran)with Julian Day (JD)}

By using JD, anydays on a date can be tracked. Cause the change of days occurs at 00:00:00, while JD contains the number $x x x x x x x x, 5$, then first calculation is adding JD with 1,5 and then divide by seven. ${ }^{22}$ The result of this calculation then be added with 1 which shows the number of days. In numbering the day, Julian Day starts from Sunday as the first day, Monday the second day and so on.

Then, the step to determine the Five-Day Week (Pasaran) with JD is same as determining the day, JD plus 1,5 . After that, the result is divided by 5 (number of pasaran). And the last, the result of calculation is added by 1 . In the pasaran numbering, 1 shows kliwon, 2 shows legi, 3 shows the pahing, 4 shows the pon and 5 shows wage.

Before testing the validity of hijriyyah date, it is necessary to understand somethings that need to be known in order not to be missinterpretations and debates on the results of calculations. The provisions used as a basis for calculation are as follows:

1. The beginning of the 1 st Muharram $1 \mathrm{H}$ coincide with Friday, July $16^{\text {th }}, 622 \mathrm{M}$

\footnotetext{
${ }^{20}$ Rinto Anugraha, Mekanika Benda Langit, Yogyakarta: tp, 2012, Hal 8

${ }^{21}$ Jean Meeus, Astronomical Algorithm, terj. Khafid, ttp, tp, tt, Hal. 54

22 Jean Meeus, Astronomical Algorithm, terj. Khafid, ttp, tp, tt, Hal. 58
} 
2. The Reckoning that is used is with urfi (aritmatic) reckoning i.e. the age of the moon is alternating where the old of odd month is 30 days and old of even month is 29 days except in leap years, the Dhulhijjah month is 30 days old

3. The sequence of leap years used is in the $2 \mathrm{nd}, 5 \mathrm{th}, 7 \mathrm{th}, 10 \mathrm{th}, 13 \mathrm{th}, 16 \mathrm{th}, 18 \mathrm{th}$, 21th, 24th, 26th and 29th years. Aside from those years as the base year (short years).

4. The sequence to determining the day is if 1 shows Sunday, 2 shows Monday, 3 shows Tuesday, 4 shows Wednesday, 5 shows Thursday, 6 shows Friday and 7 shows Saturday. The conversion system and also determination of the day use the Julian Day system calculation.

\section{C.6. Biography and Death Date of Omar bin Khattab}

The Prophet Muhammad did not leave a testamentary about who will succeed as Muslim leader after his death. It's seems, he submits this matter to the Muslims themselves to determine it. But the Prophet SAW reported that the khalifah period after the prophetic period lasted for thirty years and after that the authority will became a kingdom.

The Caliphate for thirty years was led by the famous prophet SAW companions who was called as Khulafaur Rasyidin. They are Abu Bakr al-Shiddiq, Omar bin Khattab, Uthman bin Affan and Ali bin Abi Talib. But there is an opinion that says that besides these four friends, Hasan bin Ali bin Abi Talib also included. Likewise with Omar bin Abdul Aziz, the eighth Caliph of the Umayyah. It is a white sheet of Bani Umayyah and a period that stands alone, has a character that is not affected by the policies of the Bani Ummayyah which is much regrettable. He is the personification of a pious and clean chaliph.

\section{C.7. The Data of Omar bin Khattab's Death Date}

Ahead of Abu Bakr's death, he appointed Omar bin Khattab as his successor. From this, the difference appears. Abu Bakr was appointed only by an Omar and 
recognized by the majority of the people, while Omar was appointed directly by Abu Bakr. With the appointment of Omar as a substitution for Abu Bakr al-Siddiq, Abu Bakr resolved the problem of the prospective successor so that there were no problems such as when the Prophet Muhammad died.

He became the second caliph and at the same time assumed the position of commander in chief of the Islamic army with a special title amir al-muminin (commander of the believers). He also got the nickname al-Faruq given by the Prophet Muhammad SAW because he can distinguish between right and wrong, good and bad.

After taking the position of caliph, Omar continued the expansion of territory that had been carried out by Abu Bakr. There were several expansions that were continued by Omar bin Khattab, among others towards Persia, Sham, Iraq, Egypt and Byzantium which is located northwest of Arabia consisting of Syria, Pelestina, Jordan, and Egypt. Among of the reasons why Islam expanded into these areas is caused; the prophet ambassador was killed by Christians in Syria by blessing of King Heraclitus.

Furthermore, there are the Nile river in Egypt and Mesopotamia which is fertile land when compared with the conditions in arid and barren Arabs. In addition, Damascus at that time was an important area which used as an international trade channel. If Islam can overcome the area, then Islam will increasingly develop outside the Arabian peninsula. Behind the expansion of territory in the political category, there is an element of preaching Islam. Alexandria, the capital of Egypt, was successfully controlled by Islam by making an agreement between Cyrus and the Muslims. Then the capital of Egypt was moved to a new city called Fustat which was built by Amr bin Ash in $20 \mathrm{H}$. The Amr Mosque still stands tall in the suburbs of Cairo until now as a witness of history that cannot be erased.

Omar carried out reforms in the field of government. He is among of the successful leaders, especially for the society's prosperity and Islamic rules that are becoming stronger. In addition, the most phenomenal policy is Omar's economic 
policy in Sawad (fertile area). Omar issued a decree, that Arabs -including the armyare prohibited from buying and selling land outside of Arabia.

Towards his death, Omar formed a team with six members, Ali bin Abi Talib, Uthman Ibn Affan, Zubair bin Awwam, Talha bin Abdullah, Saad Bin Abi Waqash, and Abdul Rahman bin Auf plus Abdullah bin Omar, but he did not have the right to be selected. The council is known as al-Shura (consultative), chaired by Abdul Rahman bin Auf.

Caliph Omar bin Khattab governed for 10 years over 6 months and 4 days. His death was very tragic, a Persian slave named Fairuz or Abu Luluah suddenly attacked with a sharp knife stab to the caliph who would establish subh prayer at the Nabawi Mosque. A stab wound that was thrust into the caliph caused serious injury until he died. ${ }^{23}$

There was a difference of opinion regarding the death of Omar bin Khattab in Islamic historical literature. This can be traced to Islamic history books such as Tārikh al-Thabari Tārikh al-Umam wa al-Mulūk, Ashāb al-Futuyā , al-Kāmil fĩ al-Tārikh, Siyar A'lām al-Nubula, al-Bidāyah wa al-Nihōyah. There are many versions about data of Omardied. In the books, some opinions say that the death of Omar is $3^{\text {rd }}, 4^{\text {th }}$, or $7^{\text {th }}$ days left in the month of Dhu al-Hijjah on Wednesday. There is also an opinion says that on Sunday, 1 Muharram $24 \mathrm{H}$. Completely, the explanation of differences in the data of Omar bin Khattab's death is elaborated as follows:

1. In the book Tārikh Al-Tabāri, It was mentioned that Abu Jafar said that there is an opinion says that Omar bin Khattab died in the month of Muharram in $24 \mathrm{H}$. While Harith said that Omar was stabbed on Wednesday, the remaining four days in Dhu al-Hijjah $23 \mathrm{H}$. Ahmad bin Thabit al-Razi informed that Omar was killed on Wednesday, four days remaining in Dhu al-Hijjah $23 \mathrm{H}$. Abu Jafar then said that Omar was killed on Wednesday, seven days remaining in Dhu al-Hijjah. Hisham bin

\footnotetext{
${ }^{23}$ Samsul Munir Amin, Sejarah Peradaban..., Hal. 103
} 
Muhammad related that Omar was killed on Wednesday, three days remaining in the month of Dhu al-Hijjah $23 \mathrm{H}^{24}$

In this al-Tabāri book, it is mentioned that there are many data on the death of Omar bin Khattab from different lines of transmission (riwayah). From the various transmission lines, the majority said that the day of Omar bin Khattab killed was Wednesday. Whereas, regarding the date there is a difference from one another. Most of them say the remaining four days in the month of Dhu al-Hijjah $23 \mathrm{H}$, while others say the three days or seven days left in the month of Dhu-Hijjah $23 \mathrm{H}$. Some even say that Omar died at the beginning of the month of Muharram in $24 \mathrm{AH}$. But, about Omar's funeral isn't stated in this book like another book.

The difference in these datas was accepted by Imam al-Tabari as is from the previous narrators (rowi) without verifying the validity of the hadith both in terms of death (matan) and sanad as was done when receiving a hadith. This is one of the negative aspects of writing the book of Târikh al-Tabari as revealed by Muhammad bin Thair al-Barzanji when he research this book.

2. Secondly, in the book Ashābu al-Futya mentioned that Omar bin Khattab bin Nafil was stabbed on Wednesday, the remaining four days in the month of Dhu al-Hijjah in $23 \mathrm{H}$ and was buried on Sunday morning, beginning of the month of Muharram in $24 \mathrm{H}^{25}$ his funeral. According to a strong opinion, Omar died on Wednesday, four days remaining in the month of Dhu al-Hijjah and no other opinion is included in this book regarding his death data except that date and day. In this book also added that the funeral of Omar bin Khattab was carried out on Sunday morning at the beginning of the month of Muharram $24 \mathrm{H}$. The data of Omar bin Khattab's death is the same as the majority narrations in the book of Tārikh al-Tabari.

3. Third, book al-Kāmil fi at-Tārikh mentioned that Omar bin Khattab still remembers Allah SWT and perpetuates his testimony until death picks him up on Wednesday night, the remaining three days in the month of Dhulhijjah in $23 \mathrm{H}$ and he was

\footnotetext{
${ }^{24}$ Abi Ja'far Muhammad bin Jarir al-Thabari, Tharih al-Thabari; Tarih al-Umam wa al-Muluk Jilid 2, Beirut. Dar al-Kitab al-Ilmiyyah. 1988, Hal. 561.

${ }^{25}$ Al-Imam Abi Muhammad Ali bin Ahmad bin Said bin Khazm al-Andalusi, Ashabu al-Futya, Beirut. Dar al-Kitab al-Ilmiyyah. 1995, Hal. 40.
} 
buried on Sunday, the beginning of the month of Muharram in $24 \mathrm{H}^{26}$ In this Ibn Athir book, death data are obtained differently from the majority of history. In this book, it is mentioned that Omar died on Wednesday night, three days remaining in the month of Dhu al-Hijjah $23 \mathrm{H}$. The majority opinions say that Omar died on Wednesday four days remaining in the month of Dhu al-Hijjah $23 \mathrm{H}$. While for the day of his funeral is same as the history listed in the book Ashāb al-Futya. He was buried on Sunday, the beginning of the month Muharram $24 \mathrm{H}$.

4. Forth, book Siyar A'lam al-Nubalā' mentioned that Ma'dan bin Abi Talha said : on Wednesday, Omar was injured, four days left of the month of Dhu al-Hijjah. Zaid bin Aslam and other friends also said the same thing. While Ismail bin Muhammad bin Saad bin Abi Waqqas said that he was buried on the day of the beginning of Muharram. $^{27}$

The data of Omar bin Khattab's death in this book is same as the majority of opinions in other islamic history books. Omar died on Wednesday, four days remaining in Dhu al-Hijjah. In addition, it was also explained that Omar was buried on Sunday at the beginning of the month of Muharram $24 \mathrm{H}$. This explanation is same as in the book Ashābu al-Futya and the book al-Kämil fi al-Tārīkh about the day and date of his death and funeral.

5. Fifth, in the book al-Bidāyah wa al-Nihāyah stated that Omar was stabbed on Wednesday, four days remaining in the month of Dhulhijjah $23 \mathrm{H}$ and was buried on Sunday, the beginning of the month of Muharram $24 \mathrm{H}$. Ibnu Jarir said that Omar was killed in the remaining three days of Dhu al-Hijjah $23 \mathrm{H}^{28}$ In this Ibn Kathir's book includes two different data of death as in the book Tārikh al-Thobari. The first narration says that Omar died on Wednesday, four days remaining in the month of Dhu al-Hijjah $23 \mathrm{H}$. This data represents the majority opinion stated in other islamic history books. While the other narrations mentioned on Wednesday, three days remaining in the month of Dhu al-Hijjah $23 \mathrm{H}$.

\footnotetext{
${ }^{26}$ Ibnu Atsir, al-Kamil fi al-Tarih Jilid 2, Beirut: Dar al-Kutub al-Ilmiyah, Hal. 448.

${ }^{27}$ Al-Imam Syamsu al-Din al-Dzahabi, Siyar A'lam al-Nubala', ... Hal. 329-330.

${ }^{28}$ Ibnu Katsir, al-Bidayah wa al-Nihayah Juz 7, ... Hal 111
} 
From various Islamic historical literature above, there are many opinions about the death of Omar bin Khattab. This difference is due to the various transmission paths accepted by the authors of the book. Based on the method of writing these history, no one wrote explicitly the writing techniques used in determining the time of an moment. All time data used is based on the results of transmission. This can be seen from the sentences used in narrations such as haddatsan $\bar{a}$, akhbaron $\bar{a}$, haddatsani, akhbaroni, qīla (without including the narrators) and so on.

Writing with this methode has a negative side. Especially, when occured a differences in matan from various transmission pathways.It's was like an opinion of some scholars that expressed by Muhammad bin Thair al-Barzanji when concluding the book Tārikh al-Thabari. Among the negative notes include: ${ }^{29}$

First, there is no analysis from Imam al-Tabari. He only mentions the transmittion of history and handed over the responsibility of history validity to the previous narrator. Even though, Imam al-Tabari was a scholar of hadith and able to apply the method of the hadith by examining his sanad, without having to enter to it's matan; Secondly, Imam al-Tabari rarely mentions the previous book which was used as a reference book;

Third, Imam al-Tabari sometimes decapitates stories from an incident to mention various of narrations or beheading it because occuring some years; Fourth, Imam alTabari is too concentrated on the political side.

While in writing of Siyār A'lam al-Nubalā', Imam al-Dzahabi has conducted a criticism study and analysis. He does not allow historical events to proceed without criticism if he thinks it needs to be criticized and explained. Therefore, sometimes he rejects events that are considered unjust or also corrects historical events that are still as assumptions or supports the opinions of other writers and so on.

${ }^{29}$ Imam al-Thabari, Tarikh At-Thabari: Tarikh al-Umam wa al-Muluk Jilid 2, terj. Abu Ziad Muhammad Dhiaul-Haq, Jakarta: Pustaka Azzam. Hal 157-161 


\section{C.8. RESEARCH RESULT}

As has been explained in the previous description that the date of the Omar bin Khattab's date has many versions and opinions. These differences are as summarized in the following table:

\begin{tabular}{|c|c|c|}
\hline No & Book Title & It's Death's Data \\
\hline 1 & $\begin{array}{l}\text { Tārikh al-Thabari Tārikh al- } \\
\text { Umam wa al-Mulūk }\end{array}$ & $\begin{array}{l}\text { Night of Wednesday, 3, } 4 \text { or } 7 \text { days before Dzulhijjah } \\
\text { month } 23 \mathrm{H} \text { end. In other opinion says that he was died at } \\
\text { Muharram month } 24 \mathrm{H} \text {. }\end{array}$ \\
\hline 2 & Ashāb al-Futuyā & $\begin{array}{l}\text { Wednesday, } 4 \text { days remaining of Dzulhijjah month } 23 \mathrm{H} \text {, } \\
\text { whilw the other say that he was died at Sunday, Muharram } \\
\text { month } 24 \mathrm{H} \text {. }\end{array}$ \\
\hline 3 & al-Kāmil fī al-Tārikh & $\begin{array}{l}\text { Night of Wednesday, } 3 \text { or } 4 \text { days left in Dzulhijjah month } \\
23 \mathrm{H}\end{array}$ \\
\hline 4 & Siyar A'lam al-Nubulā' & Wednesday, 4 days remaining of Dzulhijjah month $23 \mathrm{H}$ \\
\hline 5 & al-Bidāyah wa al-Nihāyah & $\begin{array}{l}\text { Wednesday, } 3 \text { or } 4 \text { days remaining of Dzulhijjah month } 23 \\
\text { H. }\end{array}$ \\
\hline
\end{tabular}

Table 1. Date of Omar bin Khattab's Death in Various Books

From this table it is obtained that the majority of historians stated that Omar bin Khattab died on Wednesday and the date of death was between 3, 4, or 7 days remaining of Dhulhijjah month $23 \mathrm{H}$. Well, for the month of his death, the majority also agreed that he died in the month of Dhulhijah $23 \mathrm{H}$. The difference in month of death is only in the book Ashāb alFutuyā, that is in Muharram month $24 \mathrm{H}$. Whereas regarding the year of his death, they also agreed that he died in the year 23 $\mathrm{H}$ except in Ashāb al-Futuyā i.e. in year $24 \mathrm{H}$.

To find out the accuracy and validity of the day, date, month and year of Omar bin Khattab's death, it is necessary to verify with the astronomical instruments to confirm amoung of these datas. The method used is converting data into the Gregorian Calendar, and checking the suitability between the date and day data. 


\begin{tabular}{lcll}
\hline \multicolumn{1}{c}{ Death's Data } & JD & \multicolumn{1}{c}{ Day } & Gregorian Date \\
\hline 7 days remaining of Dzulhijjah 23 H & 1956581,5 & Saturday & $30^{\text {th }}$ October 644 M \\
\hline 4 days remaining of Dzulhijjah 23 H & 1956584,5 & Tuesday & $2^{\text {nd }}$ November 644 M \\
\hline 3 days remaining of Dzulhijjah 23 H & 1956585,5 & Wednesday & $3^{\text {rd }}$ November 644 M \\
\hline $1^{\text {st }}$ Muharram 24 H & 1956589,5 & Sunday & $7^{\text {th }}$ November 644 M \\
\hline
\end{tabular}

Table 2. Suitability Data between Date, Day, JD and it's Gregorian Calendar

Based on the results of the conversion into the days and into the Gregorian Calendar, $4^{\text {th }}$ days before end of Dhulhijjah month $23 \mathrm{H}$ corresponds to Tuesday while for the $3^{\text {rd }}$ day before end of Dhulhijjah month $23 \mathrm{H}$ coincides with Wednesday. While the majority of opinions say that Omar bin Khattab died on Wednesday. Therefore, the exact date of the day of Omar bin Khattab's death was 26 Dhu al-Hijjah $23 \mathrm{H}$ or 3 days before end of Dhulhijjah $23 \mathrm{H}$ which coincided with November $3^{\text {rd }}, 644 \mathrm{M}$

As in the book Ashāb al-Futuyā, it is mentioned that Omar died on Sunday, 1 Muharram $24 \mathrm{H}$. In astronomical calculations, this data is correct because $1^{\text {st }}$ Muharram $24 \mathrm{H}$ coincides with Sunday or coincides with November $7^{\text {th }}, 644 \mathrm{M}$. But based on a well-known history, the majority said that Omar bin Khattab died on Wednesday, not on Sunday.

Based on the results of astronomical calculations analysis and opinion that is stronger and famous from Islamic historians, it is obtained that the date of Omar bin Khattab's death is Wednesday, $26^{\text {th }}$ of Dzulhijjah $23 \mathrm{H} / 3^{\text {rd }}$ of November $644 \mathrm{M}(3$ days remaining of Dhulhijjah $23 \mathrm{H}$ ) and buried on Sunday, $1^{\text {st }}$ of Muharram $24 \mathrm{H} /$ $7^{\text {th }}$ November $644 \mathrm{M}$

\section{Conclusion}

Based on the discussion presented, it can be concluded that: first, the cause of the differences in the data writing of Omar bin Khattab's death was due to the many different transmission paths obtained by the chroniclers and preached the information on the date of Omar bin Khattab's death with various data. The writers of Islamic history 
write data on the date of death based on information they received from previous narrators. History writers provide the discretion to the reader to be able to sort and choose data that is considered as more valid data; secondly, based on astronomical calculations and various famous historians' opinions, it is obtained that the date of Omar bin Khttab's death date was on Wednesday Pahing, $26^{\text {th }}$ of Dhulhijjah $23 \mathrm{H} / 3$ November 644 M (3 days remaining of Dhulhijjah $23 \mathrm{H}$ ) and buried on Sunday, $1^{\text {st }}$ of Muharram $24 \mathrm{H} / 7^{\text {th }}$ of November $644 \mathrm{H}$.

\section{E. Bibliography}

Anugraha, Rinto. Mekanika Benda Benda Langit, Yogyakarta, TP, 2012

Azhari, Susiknan, Ilmu Falak: Perjumpaan Khazanah Islam dan Sains Modern, Yogyakarta, Suara Muhammadiyyah, 2007, 105

el-Basyiry, Abdullah Munib. Meneladani Kepemimpinan Khalifah : Khulafaur Rasyidin dan Khalifah Pilihan. Jakarta : Amzah. 2017

Butar-Butar, Arwin Juli Rakhmadi, Problematika Penentuan Awal Bulan : Diskursus antara Hisab dan Rukyat, Malang: Madani ( Kelompok Intrans Publishing), 2014

al-Dzahabi, Imam Syamsuddin, Siyar A'lam an-Nubula, Beirut. Dar al-Kitab al-Ilmiyyah, 2010

al-Imam Abi Muhammad Ali bin Ahmad bin Said bin Khazm al-Andalusi, Ashabu al-Futya, Beirut: Dar al-Kutub al-Ilmiyah, $456 \mathrm{H}$

Ibnu Atsir. al-Kamil fi at-Tarikh Jilid 1. Beirut: Dar al-Kitab al-Ilmiyyah. 1998 M/1418 H

..m, al-Kamil fi al-Tarih Jilid 3, Beirut: Dar al-Kutub al-Ilmiyah, 1998 M/1418 H

Ibnu Jarir al-Thabari. Tarikh At-Thabari: Tarikh al-Umam wa al-Muluk Jilid 2. Beirut. Dar alKitab al-Ilmiyyah. 1988 
..... Tarikh al-Thabari; Tarikh al-Umam wa al-Muluk Jilid 3, Beirut: Dar al-Kutub al-Ilmiyah, $310 \mathrm{H} / 664 \mathrm{M}$

...., Tarikh At-Thabari: Tarikh al-Umam wa al-Muluk Jilid 2, terj: Abu Ziad Muhammad DhiaulHaq, Jakarta: Pustaka Azzam, 2011

Ibnu Katsir, al-Bidayah wa al-Nihayah Juz 7, Beirut: Dar al-Kutub al-Ilmiyah,

...., al-Bidayah wa al-Nihayah, terj. Lukman Hakim dkk, Jakarta: Pustaka Azzam, 2012

..m, al-Bidayah wa al-Nihayah. Juz 11. Beirut : Markaz al-Bihuts wa al-Dirosah al-Arabiyyah wa al-Islamiyyah. 1418 H/1998 M

Imam al-Dzahabi, Nuzhatul Fudhala Tahdzib Siyar A'lam al-Nubala, ter. Munir Abudin, Jakarta, Pustaka Azzam, 2008

Isa, Muhammad Ahsa. Sepuluh Sahabat Nabi dijamin Masuk Surga. terj. Fajar Kurnianto. Jakarta: Pustaka Imam Syafi'i. 2011

Izzuddin, Ahmad. Ilmu Falak Praktis. 2012. Semarang. Pustaka Rizki Putra

Khazin, Muhyidinn, Ilmu Falak dalam Teori dan Praktek, Buana Pustaka, 2004

Meeus, Jean. Astronomical Algorithms. terj. Khafid, ttp, tp, tt

Musonnif, Ahmad. Ilmu Falak: Metode Hisab Awal Waktu Sahalat, Arah Kiblat, Hisab Urfi, dan Hisab Hakiki Awal Bulan, Yogyakarta: Teras, 2011

Nawawi, Abdul Salam. Ilmu Falak:Cara Praktis Menghitung Waktu Shalat, Arah Kiblat, dan Awal Bulan, Sidoarjo: Aqaba, 2008

al-Thai, Muhammad Basil. 'Ilm Falak wa al-Taqwiim, Lebanon: Dar al-Nafes, 2007

Aplication 
Badan Pengembangan dan Pembinaan Bahasa, Kementerian Pendidikan dan Kebudayaan Republik Indonesia, Kamus Besar Bahasa Indonesia Edisi Kelima, Kamus Digital KBBI V 0.2.1 Beta (21) Dirilis 27 Oktober Tahun 2016. Update terakhir 12 April 2018 